Mariola Walczak-Mikołajczakowa Uniwersytet im. Adama Mickiewicza

w Poznaniu

mawal@amu.edu.pl
Data przesłania tekstu do redakcji: 24.04.2014

Data przyjęcia tekstu do druku: 22.05.2014

\title{
Emotywność współczesnych bułgarskich tekstów religijnych. Na przykładzie zografskiego wydania Żywotów butgarskich świętych
}

AвSTRACT: Walczak-Mikołajczakowa Mariola, Emotywność współczesnych bułgarskich tekstów religijnych - na przykładzie zografskiego wydania Żywotów bułgarskich świętych (Emotiveness of Contemporary Bulgarian Religious Texts. An Example of Zographsky Edition of Bulgarian Hagiography). "Poznańskie Studia Slawistyczne" 9. Poznań 2015. Publishing House of the Poznań Society for the Advancement of the Arts and Sciences, pp. 411-421. ISSN 2084-3011.

Usage of the word 'contemporary' in the title of this article persuades to think of issues which were undertaken by editors of this volume: is emotiveness belong only to texts published by contemporary media, or do we have to accept her limitation to media discourse, or would it be considered in wilder terms and draw attention to variety of ongoing discourses. From this point of view it undoubtedly attracts attention to religious language (characteristic for particular countries and contemporary used), which is still undefined and fragmentarily described. From this perspective author analyses the hagiography language which is included in the most recent edition of Bulgarian monastery on the Saint Athos Mount. The author wonders how influential the exigence of contemporary recipient can be or how the writing tradition. Cited numerous examples try to prove that the religious language of Bulgaria is traditional and refers to inheritance of Old Church Slavonic.

KeYwords: emotiveness; hagiography; religious tradition; religious tradition of language; tradition of translation

Zamieszczenie w tytule artykułu słowa „współczesne” ma na celu nakłonienie do refleksji nad zagadnieniem podjętym (choć nie expressis verbis) przez redaktorów niniejszego numeru „Poznańskich Studiów Slawistycznych”: czy emotywność przynależna jest tylko tekstom publikowanym przez współczesne media, czy należy się godzić z jej zawężaniem do dyskursu medialnego, czy też należałoby ją rozpatrywać w szerszych kategoriach i zwrócić uwagę na różnorodność toczonych obecnie dyskursów. 
Z tego punktu widzenia na uwagę zasługuje charakterystyczny dla poszczególnych krajów, używany współcześnie język religijny, wciąż wymykający się definicjom i opisywany jedynie fragmentarycznie ${ }^{1}$. W językoznawstwie polskim trwające wiele lat rozważania nad zagadnieniem, czy powinniśmy mówić o języku, o stylu religijnym, a może raczej o religijnym dyskursie nie przyniosły dotąd oczekiwanych rezultatów (Malinowska, Nocoń, Żydek-Bednarczuk 2013: 487-489). Problem dotyczy także innych języków słowiańskich, chociaż nie w każdym słowiańskim kraju rozważania nad językiem religijnym są tak ożywione, jak w Polsce, dlatego też, nie zagłębiając się w tym miejscu w podobne dyskusje, przyjmijmy za Ireną Bajerową, że językiem religijnym należy nazwać współczesną odmianę języka ogólnego wyrażoną apriorycznie nie na zasadzie formy, ale funkcji, jaką pełni w życiu społecznym, a konkretnie - w życiu związanym $\mathrm{z}$ wiarą $\mathrm{w}$ istnienie świata nadprzyrodzonego i możliwość kontaktu z nim (Bajerowa 1994: 11).

W odniesieniu do bułgarszczyzny możemy zapewne mówić - ze względu na religijną mozaikę tego kraju - o wielości języków religijnych, jednak w tym miejscu uwaga zostanie skupiona jedynie na grupie tekstów związanych z dominującą w Bułgarii religią prawosławną². Język religijny pojęty tak, jak ujmuje to Bajerowa, został niewątpliwie użyty w będącym podstawą niniejszego opracowania, współczesnym wydaniu żywotów świętych Жития на българските светии. Съдържа 64 жития на светии, почитани по българските земи, przygotowanym przez mnichów z atoskiego klasztoru Zographos (Zograf).

Pozycja ta zawiera żywoty 64 świętych, uporządkowane zgodnie z kalendarzem liturgicznym, tj. poczynając od września według dni, w których oddaje im się cześć. Żywoty uzupełnione są trzema dodatkami związanymi ze świętami, do których się odnoszą: Разказ за връщането на честните мощи на преподобния наш отец Иван от град Търново в неговата

${ }^{1}$ Cf. trudności ze zdefiniowaniem języka religijnego w polskim językoznawstwie i wielość poświęconych tej problematyce konferencji naukowych, które odbyły się w ostatnich 20 latach.

${ }^{2}$ Zgodnie z danymi Światowej Rady Kościołów z 2002 roku prawosławie w Bułgarii wyznaje $81,9 \%$ mieszkańców tego kraju, warto jednak zauważyć, że w ostatnim spisie powszechnym z 2012 roku ponad 21\% ludności nie zadeklarowało żadnego wyznania, toteż dane te mogą być znacznie zawyżone. 
Рилска обител, Разказ за празника на Светогорския български манастир «Достойно ест», Успение на свети Иван Рилски. Opowiadanie dotyczące przeniesienia relikwii patrona Bułgarii, św. Iwana Rylskiego z Tyrnowa do klasztoru w Rile 3 zamieszczono pod datą 1 lipca (zgodnie z kalendarzem religijnym, publikowanym na oficjalnej stronie Bułgarskiej Cerkwi Prawosławnej, na ten dzień przypada święto Възвръщане честните мощи на преподобния Йоан Рилски чудотвореи), tekst poświęcony jego zaśnięciu (przetłumaczony z greki) znajduje się pod datą 18 sierpnia (w tym dniu wspomina się męczenników Flora i Laura oraz śmierć św. Iwana (Св. мчици Флор и Лавър. Успение на преп. Йоан Рилски Чудотвореи), a historię związaną z bułgarską celą „Достойно ест" na Świętej Górze Athos (w tytule nazwaną klasztorem) zamieszczono pod datą 11 czerwca (według bułgarskiego kalendarza prawosławnego, jest to dzień apostołów Bartłomieja i Barnaby ${ }^{4}$ oraz Matki Bożej, czczonej w pieśni Достойно есть - znajdujemy w nim następujący zapis: $C$. апостоли Вартоломей и Варнава; Св. Богородииа [Блажи се]).

Żywoty zawarte w książce wydanej przez bułgarski klasztor Zograf (funkcjonujący na Atosie od X w.) odnoszą się do świętych, czczonych współcześnie w Bułgarii (otoczonych mniejszym lub bardziej znaczącym kultem) i w jakiś sposób związanych z nią (np. urodzonych na terenach, które dziś należą lub w przeszłości należały do Bułgarii) - wszyscy jednak objęci są wspólnym określeniem светии, просияли от българския род (święci, których blask wyszedł z bułgarskiego rodu) ${ }^{5}$. W tomie są zamieszczone zatem żywoty świętych, cudotwórców i męczenników z wieków III-XIX. Mają one różne objętość i proweniencję - niektóre są lapidarne, jednostronicowe, inne, np. żywot patrona Bułgarii Iwana Rylskiego czy otaczanej od wieków niezwykłym kultem na Bałkanach Petki Tyrnowskiej, zajmują kilkadziesiąt stron. Zróżnicowanie rozległości

${ }^{3}$ Autorem jest świadek tych wydarzeń, Władysław zwany Gramatykiem, diakon z klasztoru w Rile.

${ }^{4}$ W Nowym Testamencie apostołami nazywany jest nie tylko ścisły krąg 12 uczniów Chrystusa. Mianem tym określony jest także Barnaba, towarzysz św. Pawła w podróżach apostolskich.

${ }^{5} \mathrm{Z}$ tego względu osobnym komentarzem należałoby objąć tytuł książki zawierający określenie „bułgarscy święci” i zastanowić się nad „bułgarskością” np. prezbitera Epikteta, męczennika z III w. lub współczesnego mu mnicha Astiona, których kult notabene obecnie wydaje się martwy. 
opisów odpowiada typologii tekstów hagiograficznych, zgodnie z którą żywoty dzielimy na krótkie, odczytywane podczas liturgii (bułg. проложни) i obszerne, zamieszczane zwykle w minejach (bułg. пространни$m e)$, które były przeznaczone m.in. do indywidualnego czytania i pełniły funkcję dydaktyczną, a ich odbiorca - w zamyśle autora tekstu - miał naśladować świętego (Старобългарска литература. Енциклопедичен речник 2003: 190-191). Znaczącą część omawianego zbioru stanowią żywoty bułgarskich tzw. nowych męczenników, tzn. tych, którzy w czasach panowania tureckiego najpierw z różnych powodów dokonali konwersji na islam, a później oddali życie za wiarę chrześcijańską (Naumow 2008; Нихоритис 2001).

Żywoty męczenników, którzy poświęcili swoje życie dla wiary chrześcijańskiej w czasach przed chrystianizacją Bułgarii, są tłumaczeniami z greki, teksty dotyczące świętych znanych z historii Bułgarii były spisane (w zależności od miejsca i czasu powstania) w języku greckim, cerkiewnosłowiańskim lub słowianobułgarskim, a obecnie przetransponowano je na współczesną bułgarszczyznę. Trudno przy tym określić, czym kierowano się, wybierając tekst źródłowy, gdyż w niektórych przypadkach sięgano po źródła greckie, choć istnieją ich wersje słowianobułgarskie (przechowywane zresztą na Atosie) lub nawet wydania nowobułgarskie - tak jest np. w przypadku obszernego żywotu św. Onufrego Gabrowskiego, publikowanego już dwukrotnie: w wersji greckiej i słowianobułgarskiej oraz nowobułgarskiej (Партений 1974: 5-11; Нихоритис 2001: 272-341).

W nielicznych przypadkach pojawiają się personalia tłumaczy, rzadziej autorów, poświęca się im jednak wówczas wiele uwagi i podaje wszelkie możliwe szczegóły, w tym miejsce przechowywania rękopisów źródłowych, np.:

Преведено от гръцки език и поправено и одобрено от Всечестния проигумен и епитроп на тази света обител - Евтимий, по чиято повеля през 1802 година бе съчинена и служба на светеца (św. Kosma Zografski - przyp. M.W.-M.) за всенощно бдение. После повторно се поправи от доктора по богословие на Атинския богословски факултет, архимандрита и игумена на тази Зографска обител, Антим, на 25 август 1861 година (s. 17, żywot św. Kosmy Zografskiego ${ }^{6}$ ).

${ }^{6}$ Cytaty ze źródła (Жития на българските светии, 2002) są opatrzone numerem strony oraz polskim tytułem żywotu (jeśli nie jest podany w akapicie poprzedzającym). 
Превел от гръцки език епископ Партений Левкийски по препис от ръкописа, който се пази в библиотеката на българския Зографски манастир на Атон, и по книгите „Амартолон Сотирия”, „Атонски паметник”, „Письма святогорца о Святой Горе Атонской” и др (s. 53, żywot św. Joana Kukuzela).

Написано от блажения Теофилакт Охридски, превел (с някои ськращения) от гръцки на старобългарски и от старобългарски на съременен български език епископ Партений (s. 192, żywot św. Klemensa Ochrydzkiego).

Nie od dziś wiadomo, że żywoty nie mogą stanowić w pełni wiarygodnego źródła historycznego. Zapewne z tego powodu zografscy mnisi zdecydowali, że czas opisywanych wydarzeń nie powinien mieć dla współczesnego odbiorcy większego znaczenia - zwykle bywa określany bardzo ogólnie, z odwołaniem do wiedzy historycznej czytelnika, np. jako Диоклетиановото време lub когато турцичте воюваха с московичте, najczęściej jednak umiejscowienie wydarzeń w czasie jest zupełnie pomijane (np. w przypadku bardzo obszernego, liczącego ponad 20 stron żywota św. Kosmy Zografskiego).

Najistotniejszą jednak cechą tych tekstów, obok ich wartości religijnej, poznawczej, moralizatorskiej i dydaktycznej, jest emotywny charakter przekazu. Emotywność rozumieć będziemy dalej za Aleksym Awdiejewem jako związaną z ogólną zasadą wartościowania świata przez człowieka, odrębną kategorię funkcji pragmatycznych, która wyraża ocenę intelektualną wraz ze stosunkiem uczuciowym nadawcy do przedstawionego stanu rzeczy (Awdiejew 1987: 117). Tak rozumiana emotywność od wieków jest wpisana niejako w specyficzny gatunek literacki, który stanowią żywoty świętych, w ich retorykę. Niezmienna od stuleci pozostaje wszak struktura tych tekstów, tworzonych w trakcie przygotowań do kanonizacji danej osoby lub po uznaniu jej za świętą. Niezmieniony do dziś pozostał specyficzny układ utworów hagiograficznych, chronologia przedstawianych w nich wydarzeń, a w dużej mierze także stosowane środki językowe. Redaktorzy Encyklopedii literatury starobułgarskiej (Петканова 2003) zwracają uwagę na niezbędny w hagiografii element idealizacji, który jest głównym czynnikiem pojawienia się emotywnych środków wyrazu:

Житията (...) не съдържат цялостна биография на героя, а подбор от събития; изтъкнати са онези подвизи, които го правят светец, заслугите му за религията, църквата и нравствените му добродетели. Оттук и една основна черта на житие- 
то - идеализация на героя, който като светец вече не е обикновен човек, а «земен ангел и небесен човек» (Петканова 2003: 190).

Determinantę dla stylu tekstów źródłowych niniejszego artykułu stanowi również miejsce ich opracowania i wydania - klasztor na Świętej Górze Athos, od wieków miejsce będące strażnikiem tradycji i ortodoksji (Kuczyńska 2009). Zograf pełni dodatkowo rolę strażnika tradycji także w odniesieniu do języka tekstów religijnych. Styl zamieszczonych w zbiorze tekstów zapowiada już wstęp do tego tomu, pełen pytań retorycznych, zdań wykrzyknikowych, epitetów, metafor i porównań:

С какви похвални венци да ви увенчаем, светии, просияли от българския род, чиито имена са написани в книгата на живота?

Израснали от корена на дива маслина и в свето Кръщение присадили се към благородното дърво на Божията Църква, поели предобър подвиг от люов към Христа, вие прегърнахте елея на благодатта, с който помазвате душите на нас, празнуващите с любов честната ви памет (s. 6).

Wstęp ten kończy patetyczna odezwa do świętych nosząca cechy modlitwy:

Като почитаме вашия честен събор и празнуваме святата ви памет, светии, просияли от българския род, прилежно ви молим: молете Бога за всички нас, най-вече да запази българската земя от всякакви беди, да утвърди народа ни навеки в православната вяра, та като поживеем в мир и благочестие, да наследим заедно с вас вечното Отечество в блаженото Царство на Христа (s. 9).

Należy zauważyć, że w przypadku tekstów, które stanowią podstawę źródłową niniejszego artykułu, nie można użyć najnowszych metod badawczych, nie mają bowiem zastosowania proponowane w literaturze językoznawczej klasyfikacje emocji, oparte na opisach ich przejawów, takich jak natężenie czy barwa głosu, tempo wypowiedzi lub towarzysząca im gestykulacja - które, nawiasem mówiąc, okazują się także niewystarczające podczas analiz współczesnych aktów mowy (Rodak 2000: 187). Mamy do czynienia ze słowem pisanym o szczególnym przeznaczeniu, więc analizie językoznawczej może podlegać tylko to, co zostało wyrażone za pomocą środków językowych.

Charakterystyczną cechą wszystkich żywotów - mimo świadomości, że są spisane w nowobułgarskim języku literackim (cf. ,превел от гръцки 
на старобългарски и от старобългарски на съременен български”) jest sięganie po epitety o proweniencji cerkiewnosłowiańskiej (wyrazy złożone, rzadko używane we współczesnym języku nowobułgarskim). Niemal każdy ze świętych opisywany jest nie tylko jako преподобен, со stanowi określenie swoistej kategorii świętości, ale też богоносен, человеколюбив, добропобедния, непосрамен молитвеник, większość z nich сесhије благоразумие, добронравие, добродетел, доброговение, человеколюбива добродетел itp. Znacząca grupa stosowanych wyrazów złożonych (rzeczowników, przymiotników i imiesłowów) zawiera rdzenie благо-, добро- і люб- (co ilustrują także przytaczane poniżej cytaty).

Eksponowane przez żywoty cechy charakteru świętych i powodowane nimi zachowania są w wielu wypadkach bardzo zbliżone. Wśród najchętniej przytaczanych znajdują się:

- отличавал се със светия си живот, голямото си любомъдрие и начетеност в светите книги (s.13);

- обичал тихия, безмълвен живот (s. 14);

- знаел каква сила има смирението (s. 15);

- отвсякъде се обгради със страх божий и благоговение (s. 22);

- мисълта му летеше високо над плътта и жадуваше по-превъзходното небесно съединение (s. 22);

- и всякога бил добронравен и кротък (s. 77);

- незлобивия юноша (s. 78).

Świętych charakteryzuje też ciągłe myślenie o Bogu i strach przed sądem ostatecznym, por. „винаги имал в ума си паметта за смъртта, страшния съд Христов, мъченията на грешнците т блаженството на праведните” (s. 15), а nowych męczenników gorliwość w przygotowaniach do śmierci: „отиде в килията си, мъдро разпредели вещите си (...) раздаде милостиня, даде достатъчно пари за манастира (...) и така блаженият се заключи в онова поприще и започна духовните си подвизи" (s. 309). Jednak wśród najbardziej eksponowanych, zasługujących na wyróżnienie cech charakteru na plan pierwszy wysuwają się zamiłowanie do pracy i wrodzony talent $\mathrm{w}$ jakiejś dziedzinie, np.:

- ревностно се подвизавал на делото на непрестанно учителство (s. 13);

- усърдно се занимавал с преписване и превод на много свещени книги (s. 14);

- остроумен по природа, бързо напредваше (s. 53);

- с усърдие и страдание добре изучи Свещеното Писание и на двата езика (s. 21); 
- преуспявал в четенето и изучаването на Божествените книги и всякога бил добронравен и кротьк (s. 77).

Nic w tym dziwnego, skoro nawet przyjście na świat niektórych świętych zawdzięczamy boskiej ingerencji: „роди се по обещание, испросен с молитва от Бога” (s. 19), „чедо на благословението” (s. 20). Podkreśla się także ubogie pochodzenie wielu świętych, przy jednoczesnych ogromnych zaletach ducha ich rodziców:

- родом българин, сираче по баща (s. 53);

- бедната по произход, защото беше дъщеря на един беден и неизвестен християнин, който имаше четири дъщери, а богата по даровете на своето предизбрание и на своята природа: предизбрание по нейната гореща вяра в Бога, девство и целомъдрие, и хубост, и красотата на лицето (...) (s. 83-84);

- майка му благочестива и благолюбива го даде да се учи на Свещените Писания (s. 53);

- родил се от благочестиви родители (s. 77);

- благочестиви, благородни и известни с добродетелите си родители (s. 19);

- родителите му (...) бяха изпълнени с добродетели и праведни пред Бога и пред човеците (s. 20);

- благочестивата му и благоразсъдителна майка (s. 20).

W żywocie św. Kosmy Zografskiego można przeczytać, że na uznanie i nazywanie błogosławionymi zasługują wszyscy rodzice, którzy wydali na świat osoby święte: „О, блажени са родителите, родили чеда, заради които вечно се прославят!” (s. 20). Większość żywotów zamieszczonych w omawianym tomie ma, odziedziczony ze średniowiecznej retoryki i związany ściśle z emotywnością, poetycki charakter, nawiązujący do używanego podówczas powszechnie (w tekstach o charakterze zbliżonym do omawianych) stylu „splatania słów” („плетение словес”). Językowy obraz środowisk, w których wychowywali się święci, jest przepełniony więc epitetami, np. „горещите им молби, скръбта и техните горчиви сълзи” (s. 79), „чудесно призоваване на незлобивият юноша” (s. 78).

$\mathrm{Na}$ emotywny charakter tekstów wskazują także, odwołujące się do odpowiednich ustępów biblijnych, porównania (np. „Цялата Атонска гора, подобно на Рахил, оплакваше чедата си") oraz licznie stosowane metafory:

- Тези думи на блажените мъже бяха така неприятни за латинниците, както са неприятни камъните, хвърлени с прашка, за вълка (s. 69). 
- Посрамените от Бога ксиропотамски монаси осъзнаха престъплението си, плакаха горко и като птици без гнезда се скитаха по горите, без да има къде да одслонят глави, понеже техният манастир беше напълно разрушен заради престъпленията им (s. 72).

- (...) станал подобен на свиреп звяр. И като дивите зверове, когато видят кръв, стават още по-свирепи, така и мъчителят, при вида на кръвта на мъченика, се изпълнил с още по-люта ярост (s. 80).

- И така добрата Злата, изпитана и просияла като злато в пеща на толкова мъчения, предаде светата си душа в ръцете на своя безсмъртен Жених, като получи двоен венец - на девството и на мъченичеството (s. 87).

Głęboko przesycone emotywnością są również określenia stosowane wobec wrogów prawosławnych chrześcijan. Najwięcej tego typu epitetów znajdziemy w tekście poświęconym 26 męczennikom zografskim, którzy zginęli z rąk katolików (konsekwentnie nazywanych tu heretyckimi łacinnikami i bezbożnikami: „нечестивите, беззаконниците, нечестивите еретици, злочестните, богомерзките римляни, пълни с съблазни и безумия") oraz w żywotach tzw. nowych męczenników, którzy ponieśli śmierć z rąk Turków („озверелите агаряни, учител на мохамеданската заблуда, посраментата агарянка, похотливата туркиня” itp.).

Błędem - ze względu na źródła, z których dokonywano przekładu byłoby jednak sądzić, że wszystkie żywoty cechuje jednolity styl. Zdarza się bowiem narracja w formie dialogowej, potrzebna dla ukazania racji świętych i używanych przez nich argumentów (np. żywot Joana Kukuzela, żywot 26 zografskich męczenników, fragmenty żywotów św. Onufrego Gabrowskiego i Akakiusza z Seres). Dialogi są niewątpliwie innowacją wprowadzoną przez autorów współczesnego wydania. Poza tym żywot 26 zografskich męczenników, którzy zginęli z rąk łacinników z jednej strony odwołuje się do współczesnego stylu naukowego (podawane są daty, opatrzony jest obszernymi przypisami, w których przytacza się historyczne dane), z drugiej zaś nawiązuje do stylu publicystycznego i przypomina współczesne relacje prasowe:

След това латинниците отидоха в Иверската (Грузинската) лавра и поискаха от тамошните монаси и те да се съединят с тях. Монасите от този манастир не само не склониха на това, но изобличиха нечестивците (...) и ги проклеха за тяхното нововъведение. Беззаконниците, като чуха това се разяриха и като извлякоха всички братя извън манастира, натовариха старейшите на кораб и заедно с него ги потопиха в морето (s. 63). 
W podobnym tonie są też utrzymane fragmenty żywota św. Onufrego Gabrowskiego, przy czym w większym stopniu odwołują się one do warstwy potocznej języka, a nawet zawierają niektóre formy dialektalne (cf. „го заведоха” w przytoczonym poniżej fragmencie):

Божественият Онуфрий е роден в село Габрово на Великотьрновска епархия в 1786 година от християнски родители (...) когато стигна във възраст за наука, го заведоха в училище и се учеше на българското писмо. На седемнадесет или осемнадесет години се случи, че родителите му го биха и той, оскърбен, каза дума пред присъстващи турци, че ще се потурчи. Родителите му не искаха турците да го грабнат по насилствен начнин и той си остана по-нататък християнин, както и по-рано: не направи открито изповядване на мохамеданската вяра и не получи обрезание (s. 306).

Teksty uwzględnione w tomie Жития на българските светии nie są więc w pełni jednorodne, cechuje je nie tylko rozpiętość między lapidarną informacją a rozbudowaną opowieścią, ale także różnorodność stylistyczna (nie zawsze uzależniona od źródeł), na czym zaważył zapewne fakt, że jest to opracowanie zbiorowe. Zatem tak, jak różna była wrażliwość językowa twórców nowobułgarskich wersji żywotów świętych i ich stopień przywiązania do piśmienniczej tradycji cerkiewnosłowiańskiej, tak też różne są poszczególne teksty, oscylujące między wiernymi tłumaczeniami dzieł średniowiecznych i współczesnymi biografiami, dość rzetelnymi opracowaniami historycznymi i ludowymi relacjami. We wszystkich jednak dominuje pierwiastek emotywny. Za pomocą odpowiedniego, silnie nacechowanego słownictwa, nawiązującego do najlepszych tradycji bułgarskiej literatury religijnej, osiągnięto podstawowy moralizatorsko-dydaktyczny, ale także estetyczny charakter współczesnego opracowania, w którym święci jawią się jako ,ziemscy aniołowie i niebiańscy ludzie".

\section{Literatura}

Awdiejew A., 1987, Pragmatyczne podstawy interpretacji wypowiedzeń, Kraków. Bajerowa I., 1994, Swoistość języka religijnego i niektóre problemy jego skuteczności, „Łódzkie Studia Teologiczne” nr 3, s. 11-17.

Kuczyńska M. (red)., 2009, Święta Góra Athos w kulturze Europy. Europa w kulturze Athosu, Gniezno. 
Malinowska E., Nocoń J., Żydek-Bednarczuk U. (red.), 2013, Style współczesnej polszczyzny. Przewodnik po stylistyce polskiej, Kraków.

Naumow A., 2008, W poszukiwaniu utraconej tożsamości - nowi męczennicy atoscy (1590-1830), w: Religijna mozaika Bałkanów, red. M. Walczak-Mikołajczakowa, Gniezno, s. 43-54.

Rodak R., 2000, Frazemy jako emotywne operatory interakcyjne, w: Język a kultura, t. 14, Uczucia w języku i tekście, red. I. Nowakowska-Kempna, A. Dąbrowska, J. Anusiewicz, Wrocław, s. 187-198.

Нихоритис К., 2001, Света Гора Атон и българското новомъченичество, София. Партений (Левкински еп.), 1974, Жития на българските светии, София.

Петканова Д., 2003, Старобългарска литература. Енциклопедичен речник, Велико Търново.

\section{Źródła}

Жития на българските светии. Съдържа 64 жития на светии, почитани по българските земи, 2002, Света Гора Атон, Славянобългарски манастир „Св. Вмчк Георги Зограф".

$<$ www.bg-patriarshia.bg $>$ 